\title{
인도네시아 원조공여국(CGI) 중간점검회의 개최 보고
}

\section{| . 핵심요지}

$\square$ 금년도 CGI mid- term review 회의가 10월 3일 (월) 한국을 포함, 대인도네시아 공여국 대표 및 세 계은행, IMF, ADB, UNDP 등 국제기구 대표들 참석하여 인도네시아 보르부도르 호텔에서 개최 되어 현인도네시아 경제상황, 2005 2006년도 정 부 예산안 및 MDGS에 따른 인도네시아 빈곤 퇴 치정책에 대한 설명 및 협의가 있었음.

- 공여국 대표로는 우리나라 대사 및 미. 일.

독. 불 대사 등이 참석하였으며, 인도네시아 정 부측에서는 경제조정장관, 복지조정장관, 재무 장관 및 국가개발계획청장이 참석

$\square$ 인도네시아 정부측의 최근 유가인상 단행에 대해 대부분의 공여국 및 국제기구 대표들은 동조치가 인도네시아 거시경제 및 균형 재정 달성에 기여 할 것이라고 환영하고 인도네시아 정부의 용단을 평가함. $\square$ 인도네시아 정부는 국내유가인상을 통해 절약된 정부 재원 중 상당부분을 15.5 백만명의 빈민층에 게 직접현금지원(5조 $\mathrm{Rp})$, 학교운영지원(6.3조 $\mathrm{Rp})$, 기초보건지원(3.9조 $\mathrm{Rp})$, 시골지역기간산업 지원(3.3조 Rp) 등에 사용 예정임을 발표하였으 며, CGI 멤버들은 동조치가 투명하게 추진될 것을 주문함.

$\square$ 차기 CGI 연례회의는 2006년 3 4월경 개최키로 합의함.

\section{II. 바크리 경제조정장관의 현인도네시아 경제상황 설명}

\section{1 발리 폭탄 테러 영향}

$\square$ 금번 테러가(2002년 발리 1차테러에 비교시, 인도 네시아 경제전반에 미치는 영향이 크지 않을 것이 라고 전망 ; 발리는 인도네시아 전체 GDP의 $18 \%$ 
차지)하고, 주재국 정부가 테러범들을 발본색원함 으로써 국제사회의 신뢰를 잃지 않기 위해 노력할 것임을 천명함.

- 금년 말까지 관광객이 $20 \%$ 줄어들 경우, 이는 인도네시아 GDP에 - 0.3\% 영향을 줄 것임(인도 네시아 전체 관광 수입은 GDP의 $5 \%$ 차지).

- 인도네시아 경찰청 부청장이 발리 폭탄 테러 현 황 브리핑 실시

2. 10.1 국내유가인상 단행 자체 평가 및 대책 $\square$ 국내유가의 대폭적인 인상으로 단기적으로는 서 민들에게 어려움을 줄 것이지만, 중 장기적으로 는 경제의 지속적 안정에 기여할 것이며, 금번 유 가인상은 국민들에게는 비인기 정책이지만, 결국 국민들을 위한 정치적 부담을 각오한 어려운 선택 이었음.

- 보완책 : 서민들에 대한 직접현금 지불제도 도 입(1가정당 분기별 $300,000 R p$ 를 내년말까지 지원), 기업들에 대해 규제철폐 및 세제혜택 등 부여 방안 검토중

- 인플레 대책 : 유가인상으로 인해 높은 수준의 인플레가 예견되나, 정부로서는 이자율 추가 인 상 등 연말까지 한자리수 범위내에서 인플레 억 제를 위해 최대한 노력 예정

3. 투자유치 및 개혁정책

투자유치

- 유도요노 대통령은 외국투자유치를 위해 세일 즈 외교를 강력 전개하고 있으며, 동 노력의 결
과로 금년 1 7월간 대인도네시아 외국인 투자 가 전년대비 $79 \%$ 증가한 바, 향후에도 CGI 멤 버들의 대인도네시아 투자 확대를 당부

$\square$ 개혁정책(외국인 투자환경 개선 노력)

- 신투자법안 : 조만간 국회에 제출 예정

- 5개 세제 개정안 : 9월초에 이미 국회에 제출되 었으며, 2006년 초까지 국회 통과 전망

$\square$ 인도네시아 항만에서의 하역비용(Terminal Handling charge : THC)을 20피트 컨테이너당 150 미불에서 90 미불로 인하 예정임을 발표

\section{4. 기간산업 현황}

$\square$ 금년 1월 개최된 제1차 인프라 서미트에서 발표된 91개 프로젝트의 입찰 실적이 저조한 것은 사실이 지만, 현재 총연장 $104 \mathrm{~km}$ 고속도로 사업자를 선정 중 및 13 개 고속도로 프로젝트 $(693 \mathrm{~km})$ 가 재입찰 중이며 가스 파이프 라인 프로젝트(깔리만탄 자 바 연결), 발전소 건설 등이 진행되고 있음.

$\square$ 기간산업의 효율적 투자유치를 위해 부지 강제 매 입관련, 대통령령 발표 등 투자환경 개선을 위해 노력중임을 소개

\section{III. 안와르 재무장관의 2005, 2006년도 예산안 설명}

$\square$ 2005년 예산안이 국제고유가, Rp화 환율 불안정, 아체 쓰나미 복구비 지불, 석유보조금 삭감, 지방 선거 실시 등 국 내외적 요인으로 인해 2005년 


\begin{tabular}{|c|c|c|c|c|}
\hline 구분 & 2005년도 초안 & $\begin{array}{l}\text { 2005년도 } \\
\text { 1차 수정 예산 }\end{array}$ & $\begin{array}{c}2005 \text { 년도(9.27) } \\
\text { 2차 수정 예산의회 통과 }\end{array}$ & $\begin{array}{c}2006 \text { 년도예산인 } \\
\text { (미확정) }\end{array}$ \\
\hline $\mathrm{GDP}$ 성장율 & $5.4 \%$ & $6 \%$ & $6 \%$ & $6.1 \%$ \\
\hline 환율(1미불) & 8,600 & 9,300 & 9,800 & 9,900 \\
\hline 인플레율 & $5.5 \%$ & $7.5 \%$ & $8.6 \%$ & $8.0 \%$ \\
\hline 3개월 이자율 & $6.5 \%$ & $8.0 \%$ & $8.4 \%$ & $9.5 \%$ \\
\hline 유가(배럴) & $\$ 24$ & $\$ 45$ & $\$ 54$ & $\$ 57$ \\
\hline GDP (명목) & 2,560.9조 Rp & 2,624.3조 $\mathrm{Rp}$ & 2,6512조 $\mathrm{Rp}$ & 3,021조 Rp \\
\hline GDP 대비 재정적자 비율 & $0.7 \%$ & $0.8 \%$ & $0.9 \%$ & $0.7 \%$ \\
\hline
\end{tabular}

중 인도네시아 정부 예산안 중에서 최초로 2치례 나 수정하게 됨.

$\square$ 2005년도 1, 2차 수정 예산안 및 2006년도 예산 안(검토중)에 반영된 주요 거시경제 지표

$\square$ 2006년도 예산안 주요 검토내용

- 석유 보조금 절약으로 인한 재원의 개발재원으 로의 전용, 공무원 보수인상, 지방교부금 증액 등

\section{3. 인도네시아 대외채무}

\begin{tabular}{c|c|c}
\multicolumn{2}{c}{ (단위:Us\$) } \\
\hline 2004 & 2005.6 월 & 증감율 \\
\hline 1370억불 & 1363억불 & $-0.73 \%$ \\
\hline
\end{tabular}

4. CGI 멤버들에 대한 요청사항

$\square$ 아체 쓰나미로 인한 각국의 인도네시아 채무유예 결정에 대해 감사를 표시하고, 향후 좋은 조건의 대인도네시아 차관(softloan) 제공을 요청(40년간 무이자 차관제공 등)
IV. 복지조정장관 및 국가개발계획청 장의 주재국 빈곤퇴치 전략 소개 (MDGS 목표 달성과 연계)

1 빈곤퇴치는 인도네시아 정부의 중기 국가개발 계획(2005 2009년)의 핵심 목표로 2009년 까지 빈민층을 $8.2 \%$ 로 낮출 예정

$\square$ 중앙 정부차원에서 작성한 빈곤퇴치전략(poverty reduction strategy plan)에 따라 33개주 및 이하 소행정단위까지 모든 하위 레벨의 자체 빈곤퇴치 전략이 완성

- 8개의 구체적인 행동계획을 마련

- SMES에 대한 지원 강화, 서민들에 대한 micro credit 지원 강화

$\square$ 중앙 각부처의 정책에 빈곤퇴치가 주요 정책 사안 으로 반영(main streaming process)

2. 빈곤퇴치 과정에서 부패방지 노력 설명 $\square$ 중앙정부의 서민지원 자금 지원방식의 변경 - 유가인상 보상책으로 지급되는 현금, 학교운영 
지원비 및 건강 치료비 등이 과거처럼 지방행정

기관을 통해 수혜 대상자들에게 전달되지 않고, 중앙정부가 직접 지방 우체국, 학교장 및 의료 보험회사 등에 송금하는 제도 운영을 통해 중간 에서 자금이 유용되는 것을 원천적으로 방지

3. 10.1자 국내유가인상으로 절약된 정부예산을 직접 서민들 지원비로 전용

$\square$ 빈민층 가정(15.5백만 가구)에게 1개월 100,000Rp (약 10미불)씩 약 1년간 지원(5조 Rp), 이후 지원여 부는 추가 검토 예정

$\square$ 기타 학교운영지원(6.3조 Rp), 기초보건지원(3.9 조 Rp), 시골지역 기간산업지원(3.3조 Rp) 예정

\section{CGI 멤버들의 언급내용}

\section{1 일본대사}

$\square$ 유류인상 조치 환영

$\square$ 금년 말까지 쓰나미관련 채무이행 모라토리엄이 종료되면 내년부터는 균형재정 유지가 어려워 질 것이며, 일본 정부는 세계은행, $\mathrm{ADB}$ 등과 협조, 인도네시아 정부 지원 예정

$\square$ 빈곤퇴치사업 지원 강화를 위해 기간산업프로젝 트에 집중된 기존의 일본 ODA 중 일부를 빈곤층 보호프로젝트로 전환을 검토할 예정

$\square$ 현재 국회가 검토 중인 세제개혁안이 가지고 있는 문제점 지적하고 보완을 요청

- 세리공무원과 납세자의 동등 대우 문제(세리공
무원의 월권 가능성)

- 납세자가 납세액을 스스로 산정하는 문제

2. 한국대사

$\square$ 10.1자 유가인상 내용 중 서민들이 사용하는 가정 용 kerosine이 가장 많이 인상(185.7\%) 되었는 바, 향후 이에 대한 보완책으로 실시되는 직접현금지 불제도가 장기적으로 잘 운영되기를 기대

$\square$ 대폭적인 유가인상으로 인해 주로 기업인으로 구 성된 한국인 커뮤니티는 인도네시아 정부에 대해 1차적으로 사회적 안정을 도모해 달라는 입장임 을 전달

\section{IMF}

$\square$ 인도네시아 정부의 균형 예산안을 평가하나, 내년 부터 대외채무 지불유예가 종료될 경우에 대비할 필요성 지적

$\square$ 공정한 재원 분배, 부패방지가 복지예산 집행의 관건임을 언급

$\square$ 2006년부터 도입 예정인 조세사면제도(tax amnesty)가 정부 재정수입에는 기여하겠지만, 도 덕적 해이를 야기할 수도 있는 바, 집행에 신중을 기할 필요성 지적

\section{4. 세계은행 및 UNDP}

$\square$ 금번 인도네시아 정부의 서민들에 대한 직접 현금 교부는 최근 수년 기간중 최초로 정부가 국민들에 게 복지 비용을 직접 집행한 사례로서 높게 평가 하며, 향후 서민들에 대한 복지개선(의료, 교육)에 
실질적인 변화가 있기를 요망

$\square$ 인도네시아 정부가 향후 절약된 재원을 어떻게 지혜롭고, 투명하게 사용하느냐가 중요한 문제임 을 언급

\section{VI. 관찰 및 평가}

$\square \mathrm{CGI}$ 중간 점검회의는 매년 당초 7- 8월 개최되 나, 금년도에는 지연 개최 되었으며, 10.1자 국내 유가인상 단행 및 발리 폭탄테러에도 불구하고 인도네시아 정부가 대인도네시아 원조공여국들 에 대한 신뢰 확보 및 국내유가인상 정책에 대한 국제적 지지 도출을 위해 개최한 것으로 보이며, 회의를 통해 대부분의 CGI 멤버들이 인도네시아 정부의 정책을 지지함으로써 인도네시아 정부로 서는 소기의 성과를 달성한 것으로 평가됨.

- 금번 발리 테러에도 불구, 인도네시아 주식시장
은 10.4일 0.4 퍼센트 주가 상승을 기록하였으 며, 환율도 안정세를 유지

$\square \mathrm{CGI}$ 멤버들은 인도네시아 정부에 대해 유가인상 으로 절약된 재원을 서민복지에 전용하는 과정이 투명해야 할 것임을 언급한 한편, 인도네시아 정 부가 원하는 외국인 투자유치 확대를 실현시키기 위해서 현재 추진중인 부패척결, 규제철폐, 개혁 법안(신투자법, 세법 개정안 등)의 조속 국회 통 과 등의 가시적인 조치가 이행되어야 함을 재차 강조함.

$\square$ 한편, 바크리경제조정장관은 회의 말미에 향후 $\mathrm{CGI}$ 의 운영방식, $\mathrm{CGI}$ 의 역할 등에 재검토가 필요 하다는 의견을 제시하고, 내년도 CGI 연례회의 (3 4월경) 이전에 동건을 실무차원에서 협의해 나 가자고 제안함.

[자료 : 주인도네시아 대사관] 